\title{
APPLICATION OF CARBONACEOUS HOUSEHOLD WASTES AS FUEL FEEDSTOCK AT THERMO METALLURGICAL EQUIPMENT AND PROCESSES
}

\author{
Aleksei Viktorovich Boikov' ${ }^{1}$ Pavel Vladimirovich Ivanov' \\ 1 National Mineral Resources University (Mining University), Vasilyevsky Island, 21st line 2, 199106, Saint- \\ Petersburg, Russia, e-mial: boikov_av@mail.ru; handra@bk.ru
}

Received: 2016.02.27

Accepted: 2016.06.01

Published: 2016.07.01

\begin{abstract}
The possibility of utilization of municipal solid waste in the conveyor roasting cement production machine along with obtaining secondary thermal energy, what could reach $15-20 \%$ of the principal quantity of the heat energy required for the conduct of the process was considered. The inclusion of ash obtained from the incineration of municipal solid waste after preprocessing into the cement clinker composition was proposed. The reduction of the emission of dioxins and furans in the atmosphere and the impact on the environment was achieved as a result.
\end{abstract}

Keywords: MSW, thermal treatment, RDF, conveyor kiln, ecology

\section{INTRODUCTION}

Continuous accumulation of municipal solid waste (MSW) makes waste management more and more urgent issue with the least negative impact on the environment. Industrial disposal of municipal solid waste should be realized with three necessary conditions:

- negative effects on the environment should be decreased;

- the process has to be rational and possible to complete the integrated use of raw materials and energy with a minimum of waste from the process;

- the process waste end products have to be harmless and suitable for use.

On the other hand, it is becoming increasingly important to use alternative sources of energy every year, including the energy potential of municipal solid waste.

\section{STUDY AREA}

Municipal solid wastes (MSW) can be regarded to be low-calorie fuel with the characteristics similarly with some sorts of brown coals (see Table 1) [Feoktistov 2009]. The opportunity of using MSW as fuel is based on morphological composition of MSW which contains up to $70 \%$ of organic (combustible) fraction with carbon about 35\%. MSW unlike fossil coal are an inexhaustible, constantly generating resource.

The most effective method of MSW treatment for nowadays is incineration. The volume of the MSW reduces in 5-8 times and weight in 3-5 times during incineration. It is an environmentally safe method of MSW utilization when specific conditions are met (absence of underfired particles, the presence of flow gases at high temperature zone more then 2 seconds). Traditional incineration process produces ash as parasitic output (approximately $30 \%$ of incinerated wastes), which need to be landfilled at special places or after calcining must be utilized for building purposes [Mikhailov and Feoktistov 2009].

It becomes more feasible to burn extracted from raw MSW fuel fraction (RDF - Refuse derived fuel) and produce heat and electric power opposite to conventional utilization of raw MSW [Feoktistov 2009, Purim 2002]. On the other hand, incineration at specialized "Waste -ToEnergy" plants (WTE plants) became more expensive (especially gas cleaning systems) and it 
Table 1. The characteristics of some sorts of low-calorific fuels

\begin{tabular}{|c|c|c|c|c|c|c|c|c|}
\hline \multirow{3}{*}{ Fuel } & \multicolumn{7}{|c|}{ Working mass } & \multirow{3}{*}{$\begin{array}{l}\text { Net calorific value } \\
Q_{u}^{p} \text {, mega joule / } \\
\text { kg (average) }\end{array}$} \\
\hline & \multicolumn{7}{|c|}{ Content, \% } & \\
\hline & $\mathrm{C}^{\mathrm{P}}$ & $\mathrm{H}^{\mathrm{P}}$ & $\mathrm{O}^{\mathrm{P}}$ & $\mathrm{N}^{\mathrm{P}}$ & $S^{P}$ & $A^{P}$ & $W^{P}$ & \\
\hline MSW & 21,8 & 2,9 & 14,6 & 1,0 & 0,1 & 14,2 & 45,4 & 7,2 \\
\hline Brown coal & 29,1 & 2,2 & 8,7 & 0,6 & 2,9 & 23,5 & 33,0 & 10,5 \\
\hline Natural shale & 13,5 & 1,8 & 4,3 & 0,3 & 3 & 59,2 & 17,5 & 5,81 \\
\hline
\end{tabular}

is more favorable to sent wastes for processing in cement and metallurgical furnaces [Volkov et al. 2001]. However the technology of MSW incineration in traditional incinerators with moving grates and heat utilization systems with deriving a vapor and an electrical power on its basis has low boiler efficiency (about 25\%). It is caused by the low calorific value, the complexity of multicomponent and irregular MSW composition that makes for instability of process and significant heat loss [Feoktistov et al. 2009a].

Source MSW has a heating volume within $4-11 \mathrm{MJ} / \mathrm{kg}$. MSW include $40-50 \%$ of high-energy components, such as plastics, rubber, cardboard. Increasing of such content as moisture and "ballast" fraction (sand, stones, glass, bones, metal) reduction are the main objects of MSW enrichment for purposes of fuel deriving. For profitability guaranteeing, heating volume of the prepared RDF must be not lower than $15 \mathrm{MJ} / \mathrm{kg}$ [Lin 2006].

\section{RESULTS}

Perspective directions in technique of MSW incineration and in efficient use of heat energy are heat utilization directly in the thermal treatment unit with deriving by-products for further use.
Thereupon it is offered to use the conveyor kiln for incineration of MSW on a limestone layer using generated heat to physicochemical process of calcination:

$\mathrm{CaCO}_{3} \stackrel{t=900-1300^{\circ} \mathrm{C}}{\longrightarrow} \mathrm{CaO}+\mathrm{CO}_{2}-178$ kilo joule

This technology allows to utilize heat generated during the process of MSW incineration directly in the thermal treatment unit that allows to avoid losses of heat energy at transportation of medium (combustion gases) to the recovery boiler. The researches carried out on a pilot plant shows process-boiler efficiency of more than $50 \%$.

Conveyor kiln represents the conveyor belt, consisting of furnace bars, and roasting carts, continuously moving on a closed circle. The upper, processing, part of the conveyor belt has a charging device, a forge and technological zone for a thermal treatment of materials. The bottom part of the kiln has vacuum-chambers and flue gas gatherings. Conveyor kilns are equipped with draught-blowing devices intended both for feed of a primary air, and for recycled flue gases.

The flow diagram of MSW thermal treatment with simultaneous deriving lime is shown on the Figure 1 [Vintovkin et al. 1998].

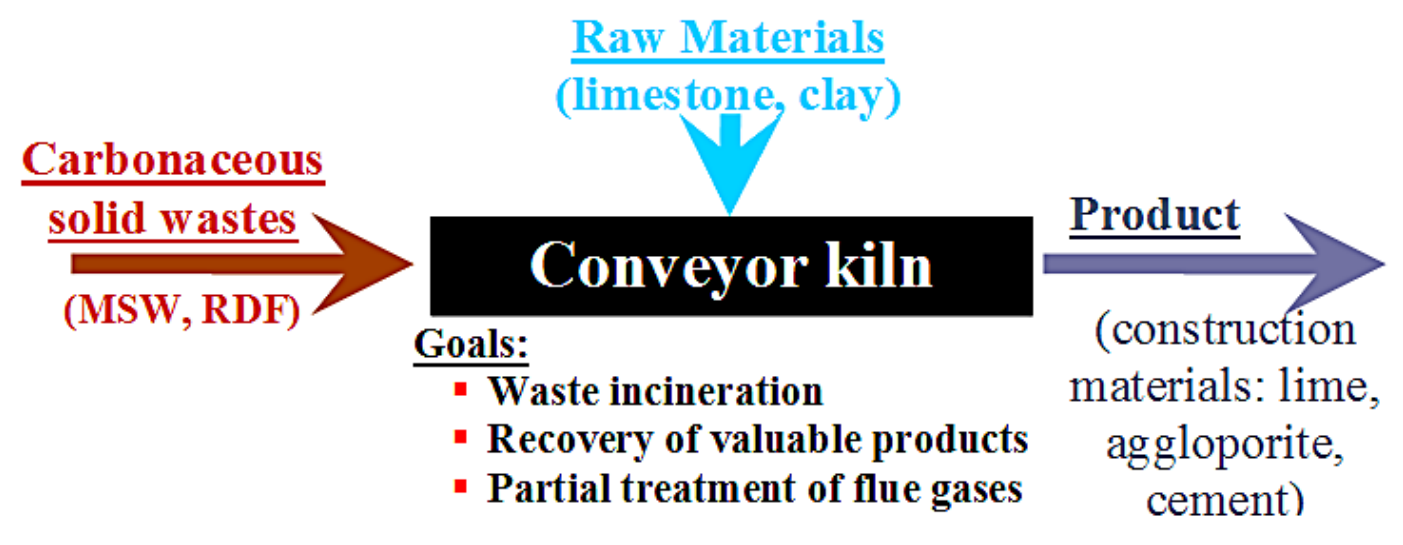

Figure 1. Conveyor kiln MSW thermal treatment concept 
The upgraded conveyor kiln is applied for MSW treatment with recuperation scheme of airgas streamflows and fractional rendering from harmful impurities immediately in the thermal treatment process.

A mixture of MSW and limestone is to be spread on a conveyor belt, ignited by means of a gas or some other kind of fuel, and burnt in a thin layer with the air being drawn through it, which is to raise the temperature up to $950-1000{ }^{\circ} \mathrm{C}$. In the process, the limestone $\left(\mathrm{CaCO}_{3}\right)$ absorbs heat and turns to lime $(\mathrm{CaO})$. The incineration results in a mixture of oxides of calcium, silicon, aluminum, and other metals. The mixture has the properties of a construction material binder and can be used as low-grade cement.

Carry-out experiments show feasibility of using conveyor kiln for calcining limestone [Feoktistov et al. 2009b]. However, low degree of limestone calcinations $(<80 \%)$ and contamination of lime with ash of MSW could cause problems with practical use of derived product. Thereupon, it is proposed to use conveyor kiln as preliminary calciner for cement carbonaceous feedstock preparing with the following clinkering in short rotating kiln. In this case, incineration ash of municipal solid waste fully combined with cement clinker.

The possibility of presence incineration ash of MSW in cement clinker could be explained by the following factors:

- Stability of chemical content ash of MSW could be obtained by separation and homogenization at MSW treatment plant;

- Partial vitrification of cement clinker at rotary kiln allows immobilize heavy metals into a nonleachable state [Lin 2006];

- Such metals as $\mathrm{Na}, \mathrm{K}, \mathrm{Pb}, \mathrm{Zn}, \mathrm{Cd}$ presented in raw wastes, transformed to volatile state and disposed of at gas cleaning systems [Lin K.L. and Lin D.F. 2006];

Lime and clay components of raw material fix $\mathrm{Cl}$ and another contaminants presented in ash of MSW and form such stable minerals as calcium-chloroaluminate $\left(\mathrm{Ca}_{12} \mathrm{Al}_{14} \mathrm{O}_{32} \mathrm{Cl}_{2}\right)$ and arinite $\left(\mathrm{Ca}_{21} \mathrm{Mg}\left[\left(\mathrm{Si}_{0.75} \mathrm{Al}_{0.25}\right) \mathrm{O}_{4}\right]_{8} \mathrm{O}_{4} \mathrm{Cl}_{2}\right)$ [Lin 2006];

Irregular composition of unsorted MSW does not allow for using it in cement manufacture as a high-quality fuel. Necessary criterion for deriving high quality cement is stable composition of raw materials, including solid fuel. MSW must be enriched to provide a stable fuel.

Vital difference of applied conveyor kiln and traditional conveyor calciner is conclude in use of different fuel for different stages of clinker processing: MSW (RDF) are used for dehydration and decarbonization (calcination) at conveyor kiln, natural gas (or another traditional fuel) are used for clinkering at short rotating kiln.

Besides the deriving valuable marketable products, this technology allows to solve the following problems:

1. Reduce the amount of wastes disposed to landfills;

2. Adsorb a part of acidic impurities (clorine, fluorine) directly by limestone layer that considerably decreases emission of dioxins and furans in the environment [Lin 2006]. Also there is a decrease of emitted sulphur oxide and binding of heavy metals;

3. Save natural mineral resources used now for calcination of limestone, prevents environmental pollution by solid wastes, e.g. slags are left;

4. Reduce emission of $\mathrm{CO}_{2}$ and $\mathrm{NO}_{\mathrm{x}}$ [Volkov et al. 2001].

\section{CONCLUSIONS}

Metallurgical furnaces by its constructive properties, temperature regimes, product characteristics and gas cleaning systems are suitable for environmental safe thermal treatment of different wastes.

Perspective metallurgical furnaces for thermal treatment of wastes are the following:

- blast furnaces;

- melting furnaces (Vanukov furnace, electroslag furnace);

- high-temperature rotating kilns;

- conveyor kilns.

Adaptation of the metallurgical equipment - the conveyor kiln, for the purposes of thermal treatment of carbonaceous household wastes with simultaneous deriving construction materials, allows to save raw fuel resources and solve ecological problems.

\section{REFERENCES}

1. Feoktistov A.Yu. 2009. Alternative fuel from municipal waste. Municipal Solid Waste, No. 3, 40-45.

2. Feoktistov A., Arsent'ev VA Beloglazov IN, Sharikov Yu.V. 2009a. Technological advantages of energy use of carbonaceous solid wastes at roast ing conveyer-based furnace. Metallurg. No. 12, 58-61.

3. Feoktistov A.Yu., Beloglazov I.N., Sharikov Y.V., Arsent'ev V.A. 2009b. Technological advantages 
of using solid carbon-bearing wastes as an energy source in a conveyor-type pelletizing machine. Metallurgist, 53(11-12), 755-759.

4. Lin K.L. 2006. Feasibility study of using brick made from municipal solid waste incinerator fly ash slag. Journal of Hazardous Materials, 137(3), 11, 1810-1816.

5. Lin K.L., Lin D.F.. 2006. Hydration characteristics of municipal solid waste incinerator bottom ash slag as a pozzolanic material for use in cement. Cement and Concrete Composites, 28(9), 817-823

6. Mikhailov N.V., Feoktistov A.Yu. 2009. The ther- mal processing of waste in the cement industry. Municipal Solid Waste, No. 2, 30-34.

7. Purim V.R. 2002. Household waste. The theory of combustion. Neutralization. Fuel for power generation. Moscow.

8. Vintovkin A.A., Ladygichev M.G., Goldobin Y.M., Yasnikov G.P. 1998. Technology and the use of fuel burning. Moscow.

9. Volkov V.I., Rusyn A.I., Ippolitov V.A., Bernadiner I.M., Torbunov V.S. 2001. Reduction of dioxin emissions at thermal neutralization of hazardous waste. Ecology and Industry of Russia, No. 1. 